FACTA UNIVERSITATIS

Series: Physical Education and Sport, Vol. 17, No 1, 2019, pp. 89 - 100

https://doi.org/10.22190/FUPES190409011U

Research article

\title{
INFLUENCE OF OBESITY ON SCHOOLGIRLS MOTOR SKILL PERFORMANCE
}

UDC 796.012.1:613.25-055.25

\section{Slavoljub Uzunović ${ }^{1}$, Goran Šekeljić ${ }^{2}$, Jovan Marković Predrag Nemec ${ }^{3}$, Danica Piršl ${ }^{1}$, Vesna Nemec ${ }^{2}$, Dejan Stošić ${ }^{4}$}

${ }^{1}$ Faculty of Sport and Physical Education, University of Niš, Niš, Serbia

${ }^{2}$ Faculty of Pedagogy in Užice, University of Kragujevac, Užice, Serbia ${ }^{3}$ Faculty of Physical Education and Sports Management, Singidunum University, Belgrade, Serbia

${ }^{4}$ Faculty for Sport and Physical Education in Leposavić, University of Priština,

Leposavić, Serbia

\begin{abstract}
The aim of this study is to compare the motor skills status of girls with different nutritional status. The research sample consisted of 180 girls aged 10 and was divided into 4 subsamples: malnourished, normally nourished, pre-obese and obese girls. The assessment of the motor space was carried out with a battery of eighteen motor tests. The identification of the differences between the groups was carried out by the Univariate Analysis of Variance (ANOVA) method. The significance of the differences between the groups was tested by the Multivariate Analysis of Variance (MANOVA) method. The results of the study suggest that obese girls had problems in variables which assessed the explosive power of the lower extremities, running speed and repetitive strength. No significant differences were found for variables which evaluate segmental speed, flexibility, precision, balance, cranial body muscle explosion, and coordination.
\end{abstract}

Key words: obesity, motor skills, girls

Received April 09, 2019/ Accepted April 18, 2019

Corresponding author: Slavoljub Uzunović

University of Niš, Faculty of Sport and Physical Education, Čarnojevića 10a, 18000 Niš, Serbia

Phone: +381 $18510900 \bullet$ E-mail: uzun@fsfv.ni.ac.rs 


\section{INTRODUCTION}

Motor skills enable different types of human motor activity. Therefore, their importance to children and their later life is immeasurable.

Physical fitness testing under controlled conditions provides important data used in the creation of a national policy for children's health, nutrition, physical education and sport (Council of Europe, 1987, in Cvejić, Pejović, \& Ostojić, 2013). Different studies (Linus et al., 2015; Poulsen et al., 2011; Sarkar, Singh, Bansal, \& Kapoor, 2011) show that overweight contributes to motor inefficiency, poor motor abilities and negative effects on overall motor development in children and adolescents. Further weakening of motor abilities increases hypokinesia that leads to obesity; obesity endangers health, and moreover fosters motor inefficiency; and thus enters the spiral of causative events that endanger public health.

Kuo, Perry, Wang, Jacobs, \& Anderson (2016) determined significant associations between body mass, eating and exercise habits, and high- risk behaviors. Obesity is a consequence of high saturated fat, a refined carbohydrate diet, and an increased input over expenditure, combined with reduced exercise (Graham, Baker, \& Davis, 2016). Obesity poses a major health problem because it has been proven as a risk factor of illness such as type 2 diabetes mellitus, glycoside tolerance disorder, early signs of liver disease, dyslipidemia, myocardial left ventricular hypertrophy, obstructive sleep apnea, orthopedic and psychosocial problems (Jackson, Djafarian, Stewart, \& Speakman, 2009; Hansson, Loyd, Anderson, \& Kopp, 2002), sleep disorders of the gallbladder (Barlow \& Dietz, 1998), deformities of the lower extremities (Petrović, Obradović, Golik-Perić, \& Bubanj, 2013), and scoliotic poor posture (Purenović, 2007). In children and adolescents with a Body Mass Index (BMI) above the $85^{\text {th }}$ percentile, the likelihood of a disorder in the cholesterol concentration is 2.4 times, for LDL-cholesterol 3.0 times, for HDL-cholesterol 3.4 times, for triglycerides 7.1 times, and blood pressure is 4.5 times higher than in normalweight children (Freedman, Khan, Dietz, Srinivasan, \& Berenson, 2001). Strong (1991) pointed out that atherosclerosis is a pediatric problem because fat deposits in the blood vessels can occur as early as in childhood, which is particularly prevalent in children with increased body mass. On the other hand, regardless of gender or type of sport involvement, studies have repeatedly shown the extensive cardiovascular, physiological, and psychological benefits associated with exercise at various level of participation (Kuo, 2012).

The aim of this study is to compare the motor skills status of girls with different nutritional status.

\section{METHODS}

In this study, 180 girls aged 10 years ( \pm 6 months) were categorized into 4 groups: a group of malnourished (30), group of normally nourished (90), group of pre-obese (30), and group of obese girls (30). We assumed that girls with normal body mass will have significantly better motor skills than girls belonging to pre-obese or obese groups.

The assessment of obesity is hampered by the lack of a simple and precise method for measuring the overall weight of body fat and the lack of clear criteria for identifying obese children (Miller, Rosenbloom, \& Silverstein, 2004; Kiess et al., 2001). The use of the BMI $\left(\mathrm{kg} / \mathrm{m}^{2}\right)$ by itself as the tool in body composition assessment, especially in the population of athletes, has been proven to be a less accurate index of body fat (Müller, 
2009), because even though a sedentary person and an athlete (active person) may have the same height and mass, their fat to fat free mass ratios may be very different. However, in everyday practice the degree of obesity is most often estimated on the basis of the BMI, since there is a satisfactory degree of correlation with direct measurement of fat content in both children and adults (Rosner, Prineas, Loggie, \& Daniels, 1998), with the thickness of the skinfold on the triceps (Malina \& Katzmarzyk, 1999), and the thickness of the waist (Jovanović, Nikolovski, Radulović, \& Novak et al., 2010). Since certain problems in the application of BMI in the assessment of the nutritional status can be attributed to large changes in body composition depending on age and gender, the values are converted into the corresponding percentiles. According to the European criteria, children with BMI above the $95^{\text {th }}$ percentile for appropriate age and sex are considered obese, while children with a BMI ranging from the $85^{\text {th }}$ to $95^{\text {th }}$ percentile are classified as overweight children. Severe or morbid obesity is defined by an index of body weight greater than the $99^{\text {th }}$ percentile (Kiess et al., 2001).

The evaluation of nine motor skills was performed by a battery of eighteen tests. Explosive strength was assessed by the Standing long jump and Medicines ball throwing tests, repetitive strength with 30 seconds Sit ups and extension, static force with the Flexed-arm hang and Hand dynamometry tests. Sprint speed was assessed by the $20 \mathrm{~m}$ Sprint test and $30 \mathrm{~m}$ Dash test, segmentary speed tests with Hand and leg tapping. Flexibility was assessed by the Deep forward bend on the bench and Split up tests, and equilibrium tests by Standing on one leg with eyes closed, and Standing on one leg along the length of the bench. Co-ordination was assessed by tests such as the Twenty steps dragging a bat, Wall Toss for 15 seconds, and precision tests Scoring a horizontal target with a ball, Scoring a vertical target - darts.

The arithmetic means (AM) and standard deviation (SD) were calculated by the means of descriptive statistics. The assessment of the motor space was carried out with a battery of eighteen motor tests. The identification of the differences between the groups was carried out by the Univariate Analysis of Variance (ANOVA) method. The significance of the differences between the groups was tested by the Multivariate Analysis of Variance (MANOVA) method. Values of $\mathrm{p}<0.05$ were considered statistically significant. All data were analyzed using the IBM SPSS (version 19.0) statistical software package for Windows.

\section{RESULTS}

The results of the MANOVA in Table 1 show statistically significant differences $(\mathrm{F}=$ 2.370; $p=0.00$ ) in motor abilities between four groups of participants.

Table 1 MANOVA results of motor abilities in relation to nutritional status

\begin{tabular}{lccc}
\hline Effect & F & Sig. & Partial Eta Squared \\
\hline Pillai's Trace & 2.301 & .000 & .227 \\
Wilks' Lambda & 2.370 & .000 & .234 \\
Hotelling's Trace & 2.441 & .000 & .242 \\
Roy's Largest Root & $4.560^{\mathrm{c}}$ & .000 & .368 \\
\hline
\end{tabular}


Table 2 Descriptive statistics and ANOVA results for testing the differences between the groups

\begin{tabular}{|c|c|c|c|c|c|c|}
\hline & \multirow{2}{*}{$\begin{array}{c}\text { Malnourished } \\
\mathrm{N}=30 \\
\mathrm{AM} \pm \mathrm{SD}\end{array}$} & \multirow{2}{*}{$\begin{array}{c}\begin{array}{c}\text { Normal } \\
\mathrm{N}=90\end{array} \\
\mathrm{AM} \pm \mathrm{SD}\end{array}$} & \multirow{2}{*}{$\begin{array}{c}\text { Overweight } \\
\mathrm{N}=30 \\
\mathrm{AM} \pm \mathrm{SD}\end{array}$} & \multirow{2}{*}{$\begin{array}{c}\text { Obese } \\
\mathrm{N}=30 \\
\mathrm{AM} \pm \mathrm{SD}\end{array}$} & \multicolumn{2}{|c|}{$\overline{\text { ANOVA }}$} \\
\hline & & & & & $F$ & $\mathrm{n}$ \\
\hline $\begin{array}{l}\text { BMI- } \\
\text { percentiles }\end{array}$ & $1.84 \pm 0.86$ & $43.80 \pm 23.54$ & $87.93 \pm 3.63$ & $95.62 \pm 0.85$ & & \\
\hline $\begin{array}{l}\text { Standing } \\
\text { long jump (in cm) }\end{array}$ & $135.76 \pm 20.74$ & $134.81 \pm 18.38$ & $125.5 \pm 14.68$ & $118.75 \pm 15.36$ & 3.790 & .012 \\
\hline $\begin{array}{l}\text { Medicine ball } \\
\text { throw (in m) }\end{array}$ & $2.86 \pm 0.56$ & $3.32 \pm 0.70$ & $3.40 \pm 0.64$ & $3.87 \pm 1.17$ & 3.409 & .019 \\
\hline $\begin{array}{l}\text { Sit-ups } \\
\text { (in reps) }\end{array}$ & $13.07 \pm 3.56$ & $14.88 \pm 3.83$ & $14.86 \pm 3.76$ & $11.0 \pm 5.47$ & 3.075 & .029 \\
\hline $\begin{array}{l}\text { Back } \\
\text { extension (in reps) }\end{array}$ & $20.07 \pm 8.86$ & $13.14 \pm 7.25$ & $13.86 \pm 8.52$ & $11.87 \pm 6.39$ & 3.302 & .022 \\
\hline $\begin{array}{l}\text { Flexed-arm } \\
\text { hang (in s) }\end{array}$ & $12.35 \pm 13.81$ & $12.46 \pm 9.51$ & $4.71 \pm 4.07$ & $3.01 \pm 3.95$ & 7.689 & .000 \\
\hline $\begin{array}{l}\text { Dynamometry } \\
\text { of a hand (in } \mathrm{N} \text { ) }\end{array}$ & $54.15 \pm 7.15$ & $61.65 \pm 12.10$ & $65.4 \pm 9.14$ & $68.0 \pm 10.39$ & 3.762 & .012 \\
\hline $\begin{array}{l}20 \mathrm{~m} \text { sprint running } \\
\text { with a flying start (in s) }\end{array}$ & $4.23 \pm 0.47$ & $3.92 \pm 0.38$ & $4.30 \pm 0.24$ & $4.6 \pm 0.22$ & 2.956 & .044 \\
\hline $\begin{array}{l}30 \mathrm{~m} \text { sprint running } \\
\text { from a standing start (in } \mathrm{s} \text { ) }\end{array}$ & $6.86 \pm 0.74$ & $6.21 \pm 0.50$ & $6.72 \pm 0.50$ & $6.75 \pm 0.37$ & 4.654 & .004 \\
\hline $\begin{array}{l}\text { Hand tapping } \\
\text { (in reps) }\end{array}$ & $27.07 \pm 4.02$ & $28.57 \pm 5.34$ & $30.43 \pm 4.37$ & $30.25 \pm 5.06$ & 1.768 & .156 \\
\hline $\begin{array}{l}\text { Foot tapping } \\
\text { (in reps) }\end{array}$ & $17.30 \pm 2.23$ & $17.63 \pm 3.71$ & $17.83 \pm 2.16$ & $15.87 \pm 2.52$ & .778 & .508 \\
\hline $\begin{array}{l}\text { Deep forward bend } \\
\text { on the bench (in cm) }\end{array}$ & $20.53 \pm 4.97$ & $19.49 \pm 5.83$ & $19.7 \pm 6.55$ & $19.87 \pm 5.90$ & .124 & .946 \\
\hline $\begin{array}{l}\text { Split } \\
\text { up (in cm) }\end{array}$ & $125.76 \pm 13.42$ & $134.61 \pm 11.37$ & $137.33 \pm 7.60$ & $136.25 \pm 14.94$ & 3.274 & .023 \\
\hline $\begin{array}{l}\text { Standing on one leg } \\
\text { with eyes closed (in s) }\end{array}$ & $4.11 \pm 1.43$ & $5.53 \pm 4.25$ & $5.72 \pm 7.87$ & $6.5 \pm 7.18$ & .420 & .739 \\
\hline $\begin{array}{l}\text { Standing on one leg } \\
\text { along the length of a } \\
\text { bench (in s) }\end{array}$ & $23.69 \pm 19.42$ & $21.55 \pm 20.59$ & $14.68 \pm 8.52$ & $26.31 \pm 28.16$ & 1.338 & .264 \\
\hline $\begin{array}{l}\text { Twenty steps } \\
\text { dragging a bat (in s) }\end{array}$ & $36.16 \pm 8.10$ & $36.07 \pm 10.28$ & $35.97 \pm 10.56$ & $36.91 \pm 7.86$ & .019 & .996 \\
\hline $\begin{array}{l}\text { Bouncing a ball } \\
\text { against the wall in } 15 \mathrm{~s} \text { (in } \\
\text { reps) }\end{array}$ & $13.07 \pm .77$ & $13.72 \pm 3.27$ & $13.36 \pm 1.94$ & $14.5 \pm 2.29$ & .497 & .685 \\
\hline $\begin{array}{l}\text { Shooting of a horizontal } \\
\text { target with a small ball } \\
\text { (in reps) }\end{array}$ & $5.84 \pm 4.09$ & $6.68 \pm 4.39$ & $7.43 \pm 4.58$ & $5.87 \pm 3.68$ & .528 & .664 \\
\hline $\begin{array}{l}\text { Shooting of a vertical } \\
\text { target - darts (in reps) }\end{array}$ & $2.46 \pm 2.70$ & $4.25 \pm 3.93$ & $4.53 \pm 3.22$ & $4.87 \pm 2.89$ & 1.122 & .342 \\
\hline
\end{tabular}

Differences between the groups (Table 2) indicate that there is a significant difference between the groups in 7 variables (the long jump: $\mathrm{f}=3.790, \mathrm{p}=.012$, medicine ball throw: $\mathrm{f}=$ $3.409, \mathrm{p}=.019$, sit-ups: $\mathrm{f}=3.075, \mathrm{p}=.022$; back extension: $\mathrm{f}=3.302, \mathrm{p}=.029$; hanging pullups: $\mathrm{f}=7.689, \mathrm{p}=.000$; running at $20 \mathrm{~m}: \mathrm{f}=2.956, \mathrm{p}=.044$; running at $30 \mathrm{~m}: \mathrm{f}=4.654, \mathrm{p}=$ .004 ; split up: $\mathrm{f}=3.274, \mathrm{p}=0.02$ ). 
Table 2 shows the descriptive statistics. The results showed that girls from the normalfed group had better results in most motor variables than girls who were classified as obese. The ANOVA results showed that there were significant differences between the groups in the results of tests evaluating explosive strength (Table 3), running speed (Table 4), repetitive muscle strength (Table 5), and muscle force (Table 6).

Table 3 Differences between the groups in explosive muscle strength

\begin{tabular}{|c|c|c|c|c|}
\hline Dependent variable & (I) BMI & (J) BMI & Std. Error & Sig. \\
\hline \multirow{12}{*}{ Standing long jump } & \multirow{3}{*}{ malnourished } & normal & 5.29465 & .857 \\
\hline & & pre-obese & 2.99162 & .029 \\
\hline & & obese & 8.10840 & .037 \\
\hline & \multirow{3}{*}{ normal } & malnourished & 5.29465 & .857 \\
\hline & & pre-obese & 3.72028 & .013 \\
\hline & & obese & 6.60963 & .016 \\
\hline & \multirow{3}{*}{ pre-obese } & malnourished & 2.99162 & .029 \\
\hline & & normal & 3.72028 & .013 \\
\hline & & obese & 7.18007 & .349 \\
\hline & \multirow{3}{*}{ obese } & malnourished & 8.10840 & .037 \\
\hline & & normal & 6.60963 & .016 \\
\hline & & pre-obese & 7.18007 & .349 \\
\hline \multirow{12}{*}{ Medicine ball throw } & \multirow{3}{*}{ malnourished } & normal & .21311 & .032 \\
\hline & & pre-obese & .24116 & .026 \\
\hline & & obese & .32636 & .002 \\
\hline & \multirow{3}{*}{ normal } & malnourished & .21311 & .032 \\
\hline & & pre-obese & .14974 & .592 \\
\hline & & obese & .26604 & .040 \\
\hline & \multirow{3}{*}{ pre-obese } & malnourished & .24116 & .026 \\
\hline & & normal & .14974 & .592 \\
\hline & & obese & .28900 & .105 \\
\hline & \multirow{3}{*}{ obese } & malnourished & .32636 & .002 \\
\hline & & normal & .26604 & .040 \\
\hline & & pre-obese & .28900 & .105 \\
\hline
\end{tabular}

Explosive muscle strength was assessed by two tests. In the Long jump test (Table 3), the girls from the pre-obese and obese group scored the worst results on average. These results are at a level of statistical significance $(\mathrm{p}<.05)$, lower than those of the group of normally and group of malnourished girls. On the Medicine ball throw test the girls from the undernourished group achieved the worst results. A group of obese girls achieved the best average score, which at the level of statistical significance $(p<.05)$ is better than the results achieved by the groups of malnourished and normally nourished girls. 
On the 30m sprint running test (Table 4), the girls from the of normal nourished group achieved a better result than the group of obese, pre-obese and malnourished girls, while on the $20 \mathrm{~m}$ sprint running test the girls from the normal-fed group achieved a better result that was statistically significant $(\mathrm{p}<05)$ when compared to the group of obese girls.

Table 4 Differences between the groups in speed of movement

\begin{tabular}{|c|c|c|c|c|}
\hline Dependent variable & (I) BMI & (J) BMI & Std. Error & Sig. \\
\hline \multirow{12}{*}{$\begin{array}{l}20 \mathrm{~m} \text { sprint running } \\
\text { with a flying start }\end{array}$} & \multirow{3}{*}{ malnourished } & normal & .10821 & .299 \\
\hline & & pre-obese & .12246 & .578 \\
\hline & & obese & .16572 & .711 \\
\hline & \multirow{3}{*}{ normal } & malnourished & .10821 & .299 \\
\hline & & pre-obese & .13509 & .199 \\
\hline & & obese & .07604 & .019 \\
\hline & \multirow{3}{*}{ pre-obese } & malnourished & .12246 & .578 \\
\hline & & normal & .13509 & 199 \\
\hline & & obese & .14675 & .964 \\
\hline & \multirow{3}{*}{ obese } & malnourished & .16572 & .711 \\
\hline & & normal & .07604 & .019 \\
\hline & & pre-obese & .14675 & .964 \\
\hline \multirow{12}{*}{$\begin{array}{l}30 \mathrm{~m} \text { sprint } \\
\text { with a standing start }\end{array}$} & \multirow{3}{*}{ malnourished } & normal & .15606 & .005 \\
\hline & & pre-obese & .17660 & .435 \\
\hline & & obese & .23899 & .194 \\
\hline & \multirow{3}{*}{ normal } & malnourished & .15606 & .005 \\
\hline & & pre-obese & 10965 & .006 \\
\hline & & obese & 1.43573 & .008 \\
\hline & \multirow{3}{*}{ pre-obese } & malnourished & .17660 & .435 \\
\hline & & normal & .10965 & .006 \\
\hline & & obese & .21163 & .414 \\
\hline & \multirow{3}{*}{ obese } & malnourished & .23899 & .194 \\
\hline & & normal & 1.43573 & .008 \\
\hline & & pre-obese & .21163 & .414 \\
\hline
\end{tabular}

By analyzing the statistical parameters (Table 5), it was noticed that girls from the obese group for the Sit-ups and Back extension, which were applied to test the repetitive muscle strength of the trunk, achieved a result that is at a level of statistical significance $(p<.05)$ better than the group of undernourished $(p<.05)$, group of normally nourished and group of pre-obese girls. A group of pre-obese girls achieved a result that is at a level of statistical significance $(\mathrm{p}<.05)$ lower than that of the group of normally nourished girls.

In the Flexed-arm hang test (Table 6), the girls from the obese and pre-obese group achieved the worst results, which are also at the level of statistical significance $(\mathrm{p}<.05)$, as compared to the results achieved by the group of malnourished and group of normally nourished girls. In the Hand dynamometry test, the weakest score was scored by the group of malnourished girls at the level of statistical significance $(\mathrm{p}<.05)$, as compared to all the other groups. 
Table 5 Differences between the groups on tests of repetitive muscle strength

\begin{tabular}{|c|c|c|c|c|}
\hline Dependent variable & (I) BMI & (J) BMI & Std. Error & Sig. \\
\hline \multirow{12}{*}{ Sit-ups } & \multirow{3}{*}{ malnourished } & normal & 1.15899 & .122 \\
\hline & & pre-obese & 1.31155 & .174 \\
\hline & & obese & 1.77491 & .244 \\
\hline & \multirow{3}{*}{ normal } & malnourished & 1.15899 & .122 \\
\hline & & pre-obese & .81436 & .986 \\
\hline & & obese & 1.44683 & .008 \\
\hline & \multirow{3}{*}{ pre-obese } & malnourished & 1.31155 & .174 \\
\hline & & normal & .81436 & .986 \\
\hline & & obese & 1.57170 & .015 \\
\hline & \multirow{3}{*}{ obese } & malnourished & 1.77491 & .244 \\
\hline & & normal & 1.44683 & .008 \\
\hline & & pre-obese & 1.57170 & .015 \\
\hline \multirow{12}{*}{ Back extension } & \multirow{3}{*}{ malnourished } & normal & .98589 & .742 \\
\hline & & pre-obese & 1.11567 & .638 \\
\hline & & obese & 1.50983 & .344 \\
\hline & \multirow{3}{*}{ normal } & malnourished & .98589 & .742 \\
\hline & & pre-obese & .69274 & .773 \\
\hline & & obese & 2.55922 & .016 \\
\hline & \multirow{3}{*}{ pre-obese } & malnourished & 1.11567 & .638 \\
\hline & & normal & .69274 & .773 \\
\hline & & obese & 3.46337 & .019 \\
\hline & \multirow{3}{*}{ obese } & malnourished & 1.50983 & .344 \\
\hline & & normal & 2.55922 & .016 \\
\hline & & pre-obese & 3.46337 & .019 \\
\hline
\end{tabular}

Table 6 Differences between the groups on the tests of static muscle strength

\begin{tabular}{|c|c|c|c|c|}
\hline Dependent variable & (I) BMI & (J) BMI & Std. Error & Sig. \\
\hline \multirow{12}{*}{ Flexed-arm hang } & \multirow{3}{*}{ malnourished } & normal & 2.67488 & .968 \\
\hline & & pre-obese & 3.02699 & .013 \\
\hline & & obese & 4.09640 & .024 \\
\hline & \multirow{3}{*}{ normal } & malnourished & 2.67488 & .968 \\
\hline & & pre-obese & 1.87950 & .000 \\
\hline & & obese & 3.33921 & .005 \\
\hline & \multirow{3}{*}{ pre-obese } & malnourished & 3.02699 & .013 \\
\hline & & normal & 1.87950 & .000 \\
\hline & & obese & 3.62740 & .640 \\
\hline & \multirow{3}{*}{ obese } & malnourished & 4.09640 & .024 \\
\hline & & normal & 3.33921 & .005 \\
\hline & & pre-obese & 3.62740 & .640 \\
\hline \multirow{12}{*}{ Hand dynamometry } & \multirow{3}{*}{ malnourished } & normal & 3.32350 & .025 \\
\hline & & pre-obese & 3.76099 & .003 \\
\hline & & obese & 5.08972 & .007 \\
\hline & \multirow{3}{*}{ normal } & malnourished & 3.32350 & .025 \\
\hline & & pre-obese & 2.33526 & .110 \\
\hline & & obese & 4.14892 & .128 \\
\hline & \multirow{3}{*}{ pre-obese } & malnourished & 3.76099 & .003 \\
\hline & & normal & 2.33526 & .110 \\
\hline & & obese & 4.50699 & .565 \\
\hline & \multirow{3}{*}{ obese } & malnourished & 5.08972 & .007 \\
\hline & & normal & 4.14892 & .128 \\
\hline & & pre-obese & 4.50699 & .565 \\
\hline
\end{tabular}




\section{DISSCUSION}

The obtained results have shown significant differences in some segments of the motor space of girls divided into four subsamples and classified according to their nutritional status. Statistically significant differences $(\mathrm{p}<.05)$ were reflected in the results achieved on tests evaluating the explosive strength of the lower extremities, running speed, repetitive strength of the trunk flexors and extensors. No statistically significant differences were found for the variables determined as segmental velocity, accuracy, equilibrium, and coordination. On the tests that assessed the flexibility and muscle explosiveness of the cranial part of the body in the obese group, they achieved better results than the group of malnourished and normally nourished girls at the level of statistical significance $(p<.05)$.

Differences have not been observed in the space of motor variables in which the body mass is not a prerequisite for an efficient solution of the motor assignment, i.e., in motor tasks where there is no great movement of the body and the movement of the lower limbs, but the tasks are solved by moving small segments of the body, by standing or sitting. Similar results were obtained in other studies (Casajus, Leiva, Villarroya, Legaz, \& Moreno, 2007; Sporiš, Badrić, \& Miljković, 2014). On the other hand, obese girls had problems on tests that required the quick movement of the entire body over long distances, and on tests that required the manifestation of power based on the movement of one's own body.

On the Standing long jump, $20 \mathrm{~m}$ and $30 \mathrm{~m}$ Sprint the obese group of girls achieved results that are at the level of statistical significance weaker when compared to the group of normally nourished girls. These are motor activities that evaluate the explosive strength of the lower limbs, the velocity of movement and, to a large extent, depend on the anatomical and physiological state of the locomotor apparatus and the system that controls postural stability (vestibular apparatus and nerve structures that are associated with different kinesthetic receptors in the muscles, bones, and joints). According to Yusof, Aiman, Zawi, Hasan, \& Radzi, 2013, the reasons for the motor abnormality of obese individuals must be due to changes in the morphology and structure of tissu and organs, as these are factors that determine motor abilities. This is confirmed by many other studies. For example, the knee axis undergoes changes during growth: there exists physiologic varus at infancy while after the age of 4-5, the valgus knee of 7-10 degrees can be found. Obesity increases the loading of the distal femoral and proximal tibial growth cartilages which can result in higher prevalence of the valgus knee (MaciałczykPaprocka et al., 2017). The skeletal structure of the lower extremities often changes due to overweight, and changes occur on the ankles, feet and fingers that increase, becoming wider, higher and thicker (Daneshmandi, Rahnema, \& Mehdizadeh, 2009; Sarkar et al., 2011). Because of the increased bone load, obese individuals are thick, but they often do not possess enough mineral density, which enhances a prevalence of musculo-skeletal pain in the area of the back, hips, legs, knees, joints and feet significantly (Taylor et al., 2006). Long-term higher pressure on longitudinal vaults under metatarsal heads can cause reduced ligament strength of the foot (Spyropoulos, Pisciotta, Pavlou, Cairns, \& Simon, 1991), which reduces the ability buffer during impact between the foot and ground (Daneshmandi et al., 2009). This structure of the feet in the biomechanical context leads to dissipation of muscular strength, reduction of the efficiency of movement and reduction of body stability (Gouws, 2010). Moreover, additional disturbances are caused by increased inflammation that affects the sensitivity of the nerve receptors in the foot arc (Miscio et al., 2005). An altered body structure creates problems in the biomechanics of movement in certain body segments, which causes clumsiness and fear of falling. 
All the above mentioned reduces the mobility of the obese, inhibits the creation of motor patterns, limits or disables various forms of motor learning (Sarkar et al., 2011). Some studies indicate a specific posture of the cranial part of the body. The characteristic posture of obese people makes valgus in the knees and ankles, hyperextension of the knees and ankles, medial rotation in the joints of the hips and pelvic anterversion. The consequences are anterior displacement of the center of gravity, and an increase in the torque in the joints (Martinelli et al., 2011). This instability aggravates the operation of the locomotor system that aligns its functioning with the vestibular apparatus and the kinesthetic receptors (D'Hondt, Deforche, De Bourdeaudhuij, \& Lenoir, 2008). In addition, other studies show that in obese people the sensitivity of mechanoreceptors found in the feet is less due to the high pressure that they tolerate on a daily basis. The reduced input of sensory information explains the lower stability of obese people (Teasdale, et al., 2013). The damaged sensomotor and neuromuscular function cause changes in the mechanics of motion. The characteristic pattern of movement is characterized by an emphasized upright stiffness of the body, a lower speed of walking, a slower step frequency, a smaller length and a greater width of the step. They walk with a reduced bending of the knees and hips, a longer pauses and pronounced periods of support on both feet (Sarkar et al., 2011).

The anatomical and physiological changes in the skeletal muscular structure and the consequences that result therefrom, in the biomechanics of the movement, can explain the poor results of the obese in motor activities with the pronounced activity of the lower extremities, on tests requiring speed, explosiveness or some other kind of dynamic strength (Siahkouhian \& Mahmoodi, 2011). A prevailing general attitude in most of the research studies is that if fine motor precision, coordination of the hands and movements in which object control skills are exhibited, then there are no significant differences (Okely, Booth, \& Chey, 2004; Southall, Okely, \& Steele, 2004). However, if an activity that requires the involvement of larger body segments or the movement of the whole body is assessed, then obese individuals achieve lower results (Savelsbergh, Bennett, Angelakopoulos, \& Davids, 2005; D'Hondt et al., 2013).

A group of obese girls achieved statistically significant lower scores on Sit-ups and Back extension and Flexed-arm hang. These are tests that evaluate the repetitive muscle strength of the trunk, the repetitive muscle strength of the trunk extensor, and the static muscle force of the elbow joint. Also, some other studies show that locomotor competencies in which dynamic muscle strength is exhibited are directly related to excess body weight and disturbed musculoskeletal functions of obese children (Graf et al., 2004). However, in the research of Deforche, De Bourdeaudhuij, D'Hondt, \& Cardon (2009), the obese have been observed to have greater absolute strength, but that in tests where it is necessary to display relative strength, they exhibit lower muscle potential. When the contractions were caused by electro-activation of the muscles in laboratory conditions, there was no difference in the muscle strength between the groups. This has led the authors to conclude that the weaker result of the obese on tests where repetitive muscular strength is emphasized is due to motivation rather than to the reduced repetitive muscle potential.

Findings in this as well as in some other studies (Sporiš et al., 2014) show significantly worse results of obese girls in the Flexed-arm hang test. However, for a lot of reasons, the question may arise as to whether obese people actually have weaker muscle strength in the elbow joint. It is more likely that the results achieved by the obese in the Flexed-arm hang test are such due to the fact that a test is not adapted to the population of obese children because it favors participants with lower body weight. Body 
weight $(\mathrm{Q})$ is equal to the product of the body mass and gravity force $(\mathrm{Q}=\mathrm{m} \cdot \mathrm{g})$, and therefore a body of $1 \mathrm{~kg}$ weighs about $10 \mathrm{~N}$. In the Flexed-arm hang, the muscles are folded into the joint of the elbow with a force that is required for the body of the participants to rise as long as possible. If in the formula for force $(\mathrm{F}=\mathrm{m} \cdot \mathrm{a})$, the acceleration "a" is replaced by the value of gravity "g" (because the body does not receive acceleration during testing, but the force of gravity is resisted by the force of the muscle) the obtained value for force $\mathrm{F}$ becomes equivalent to the weight of the body $(\mathrm{Q}=\mathrm{m} \cdot \mathrm{g})$. For this reason, the force $\mathrm{F}$ required to keep the body in the Flexed-arm hang is equal to the product of the body mass (m) and the Earth's gravity (g). Gravity is a constant size, and the body mass is a variable size. For this reason, different people need different forces to keep the body in a hanging position. For this reason, the Flexed-arm hang test is standard (performed in the same manner as prescribed in the protocol), but it is not standardized (the load is not the same for participants of different weights) (Šekeljić, Stamatović, Marković, \& Marković, 2013). Also, the results of other studies (Marković \& Jarić, 2004) indicate that it is necessary for body mass to be taken into account when testing the following motor tasks: lifting, pushing or pulling on one's own body. Such claims are corroborated by the results achieved in the Dynamometry of the hand and the Medicine ball throw tests. In this test, where the dynamometer is held by the fingertip of the hand and the strength of the fingers is estimated, the group of obese girls achieved the best result. Similar results were achieved on the Medicine ball throw test which shows that obese girls have good muscle strength and that in this segment of motor skills they do not fall behind the group of normally nourished girls.

\section{CONCLUSION}

The results of the study have shown that obese girls show some inefficiency in the motor space. Still at this age (10 years) there are no significant differences. Nevertheless, the question arises as to what will happen in the future when these differences progress. It is therefore necessary to pay due attention to this problem through various interdisciplinary cooperative concepts in order to achieve lasting effects in changing bad living habits. As part of such actions it is necessary for obese children to be included in various modeled forms of physical activity through which the improvement of inefficient motor dimensions would be carried out. Physical modeling activity is necessary to support permanent monitoring from different areas in order to assess the effects of exercise on motor skills. In order to accurately analyze movements in testing, it is necessary to use modern equipment such as kinematic cameras, dynamometer platforms to accurately determine differences in motor inefficiency. In addition, on the sample, during the treatment, it should be necessary to control the health, diagnosis of postural status and anatomical and physiological changes in the bodies of the participants.

The results of this study can contribute to a better understanding of the motor space of obese children, problems in motor activity, and methods that can be preventive from causing problems and by which problems can be resolved. 


\section{REFERENCES}

Barlow, S.E., \& Dietz, W.H. (1998). Obesity evaluation and treatment: expert committee recommendations. Pediatrics, 102(3), e29-e29.

Casajús, J.A., Leiva, M.T., Villarroya, A., Legaz, A., \& Moreno, L.A. (2007). Physical performance and school physical education in overweight Spanish children. Annals of Nutrition \& Metabolism, 51(3), 288.

Cvejić, D., Pejović, T., \& Ostojić, S. (2013). Assessment of physical fitness in children and adolescents. Facta Universitatis Series Physical Education and Sport, 11(2), 135-145.

Daneshmandi, H., Rahnema, N., \& Mehdizadeh, R. (2009). Relationship between obesity and flatfoot in highschool boys and girls. International Journal of Sports Science and Engineering, 3(1), 43-49.

Deforche, B., De Bourdeaudhuij, I., D'Hondt, E., \& Cardon, G. (2009). Objectively measured physical activity, physical activity related personality and body mass index in 6-to 10-yr-old children: a cross-sectional study. International Journal of Behavioral Nutrition and Physical Activity, 6(1), 25.

D'Hondt, E., Deforche, B., De Bourdeaudhuij, I., \& Lenoir, M. (2008). Childhood obesity affects fine motor skill performance under different postural constraints. Neuroscience Letters, 440(1), 72-75.

D'Hondt, E., Deforche, B., Gentier, I., De Bourdeaudhuij, I., Vaeyens, R., Philippaerts, R., et al. (2013). A longitudinal analysis of gross motor coordination in overweight and obese children versus normal-weight peers. International Journal of Obesity, 37(1), 61-67.

Freedman, D.S., Khan, L. K., Dietz, W.H., Srinivasan, S.R., \& Berenson, G.S. (2001). Relationship of childhood obesity to coronary heart disease risk factors in adulthood: the Bogalusa Heart Study. Pediatrics, 108(3), 712-718.

Gouws, P.L. (2010). Effects of obesity on the biomechanics of children's gait at different speeds. Doctoral dissertation. United States: University of Nevada, Las Vegas.

Graf, C., Koch, B., Falkowski, G., Jouck, S., Christ, H., Stauenmaier, K., \& Predel, H.G. (2005). Effects of a school-based intervention on BMI and motor abilities in childhood. Journal of Sports Science \& Medicine, 4(3), 291.

Graham, M.R., Baker, J.S., \& Davies, B. (2015). Causes and consequences of obesity: epigenetics or hypokinesis?. Diabetes, Metabolic syndrome and Obesity: Targets and Therapy, 8, 455-460.

Hansson, L., Lloyd, A., Anderson, P., \& Kopp, Z. (2002). Excess morbidity and cost of failure to achieve targets for blood pressure control in Europe. Blood Pressure, 11(1), 35-45.

Jackson, D.M., Djafarian, K., Stewart, J., \& Speakman, J.R. (2009). Increased television viewing is associated with elevated body fatness but not with lower total energy expenditure in children. The American journal of Clinical Nutrition, 89(4), 1031-1036.

Jovanović, R., Nikolovski, D., Radulović, O., \& Novak, S. (2010). Physical activity influence on nutritional status of preschool children. Acta Medica Medianae, 49(1), 17-21.

Kiess, W., Galler, A., Reich, A., Müller, G., Kapellen, T., Deutscher, J., et al. (2001). Clinical aspects of obesity in childhood and adolescence. Obesity Reviews, 2(1), 29-36.

Kuo, Y., Perry, A., Wang, X., Jacobs, K., \& Anderson, B. (2016). Comparison of body composition, eating habits, exercise habits, and high risk behavior in tri-racial female athletes. International Journal of Exercise Science, 8 (4), 58.

Kuo, Y. (2012). The comparison of body composition, eating habits, exercise habits, and high risk behaviors in a triracial group of division I collegiate female athletes. Doctoral dissertation, United States: University of Miami.

Linus, Z., Fabian, D., Pieter, V., Eva, D.H., Greet, C., \& Matthieu, L. (2015). Associations between cycling skill, general motor competence and body mass index in 9-year-old children. Ergonomics, 58(1), 160-171.

Maciałczyk-Paprocka, K., Stawińska-Witoszyńska, B., Kotwicki, T., Sowińska, A., Krzyżaniak, A., Walkowiak, J., et al. (2017). Prevalence of incorrect body posture in children and adolescents with overweight and obesity. European Journal of Pediatrics, 176(5), 563-572.

Malina, R.M., \& Katzmarzyk, P.T. (1999). Validity of the body mass index as an indicator of the risk and presence of overweight in adolescents. The American Journal of Clinical Nutrition, 70(1), 131s-136s.

Marković, G., \& Jarić, S. (2004). Movement performance and body size: the relationship for different groups of tests. European Journal of Applied Physiology, 92(1-2), 139-149.

Martinelli, A.R., Purga, M.O., Mantovani, A.M., Camargo, M.R., Rosell, A.A., Fregonesi, C.E.P.T., et al. (2011). Analysis of lower limb alignment in overweight children. Revista Brasileira de Cineantropometria \& Desempenho Humano, 13(2), 124-130.

Miller, J., Rosenbloom, A., \& Silverstein, J. (2004). Childhood obesity. Journal of Clinical Endocrinology \& Metabolism, 89, 4211-4218.

Miscio, G., Guastamacchia, G., Brunani, A., Priano, L., Baudo, S., \& Mauro, A. (2005). Obesity and peripheral neuropathy risk: a dangerous liaison. Journal of the Peripheral Nervous System, 10(4), 354-358.

Müller, W. (2009). Determinants of ski-jump performance and implications for health, safety and fairness. Sports Medicine, 39 (2), 85-106 
Okely, A.D., Booth, M.L., \& Chey, T. (2004). Relationships between body composition and fundamental movement skills among children and adolescents. Research Quarterly for Exercise and Sport, 75(3), 238-247.

Petrović, M., Obradović, B., Golik-Perić, D., \& Bubanj, S. (2013). Jumping abilities are not related to foot shape. Facta Universitatis Series Physical Education and Sport, 11(3), 299-305.

Poulsen, A.A., Desha, L., Ziviani, J., Griffiths, L., Heaslop, A., Khan, A., et al. (2011). Fundamental movement skills and self- concept of children who are overweight. Pediatric Obesity, 6(2), 464-471.

Purenović, T. (2007). Review of national and international research studies in postural deformities: The period from 2000 to 2007. Facta Universitatis Series Physical Education and Sport, 5(2), 139-152.

Rosner, B., Prineas, R., Loggie, J., \& Daniels, S.R. (1998). Percentiles for body mass index in US children 5 to 17 years of age. The Journal of Pediatrics, 132(2), 211-222.

Sarkar, A., Singh, M., Bansal, N., \& Kapoor, S. (2011). Effects of obesity on balance and gait alterations in young adults. Indian Journal of Physiology and Pharmacology, 55(3), 227-233.

Savelsbergh, G.J., Bennett, S. J., Angelakopoulos, G.T., \& Davids, K. (2005). Perceptual-motor organization of children's catching behaviour under different postural constraints. Neuroscience Letters, 373(2), 153-158

Šekeljić, G., Stamatović, M., Marković, Ž., \& Marković, J. (2013). Metric characteristics of the motor test used to estimate the force of arms and shoulders. Facta Universitatis Series Physical Education and Sport, 11(1), 115-124.

Siahkouhian, M., \& MahmoodiH, S.M. (2011). Relationship between fundamental movement skills and body mass index in 7-to-8 year-old children. World Applied Sciences Journal, 15(9), 1354-1360.

Southall, J.E., Okely, A. D., \& Steele, J.R. (2004). Actual and perceived physical competence in overweight and nonoverweight children. Pediatric Exercise Science, 16(1), 15-24.

Sporiš, G., Badrić, M., \& Miljković, Z. (2014). Do the overweight and obesity effect on motor ability level among girls? Sport Science, 7(2), 36-43.

Spyropoulos, P., Pisciotta, J.C., Pavlou, K.N., Cairns, M.A., \& Simon, S.R. (1991). Biomechanical gait analysis in obese men. Archives of Physical Medicine and Rehabilitation, 72(13), 1065-1070.

Strong, J.P. (1991). The natural history of atherosclerosis in childhood. Annals of the New York Academy of Sciences, 623(1), 9-15.

Taylor, E.D., Theim, K.R., Mirch, M.C., Ghorbani, S., Tanofsky-Kraff, M., Adler-Wailes, D.C., et al. (2006). Orthopedic complications of overweight in children and adolescents. Pediatrics, 117(6), 2167-2174.

Teasdale, N., Simoneau, M., Corbeil, P., Handrigan, G., Tremblay, A., \& Hue, O. (2013). Obesity alters balance and movement control. Current Obesity Reports, 2(3), 235-240.

Yusof, S.M., Aiman, S., Zawi, M.K., Hasan, H., \& Radzi, A.A.M. (2013). Body composition index predict children's motor skills proficiency. Proceedings of World Academy of Science, Engineering and Technology, 7(7), 1147.

\section{UTICAJ GOJAZNOSTI NA MOTORNE PERFORMANSE DEVOJČICA}

Cilj ove studije bio je da se uporede motoričke sposobnosti devojčica sa različitim nutritivnim statusom. Uzorak u istraživanju sačinjavalo je 180 devojčica starosti 10 godina, podeljen na 4 subuzorka: pothranjene, normalno uhranjene, predgojazne i gojazne devojčice. Procena motoričkog prostora sprovedena je baterijom od osamnaest motoričkih testova. Utvrđivanje razlika između grupa izvršeno je metodom univarijantne analize varijanse (ANOVA). Značajnost razlika u sistemu primenjenih varijabli za procenu motoričkih sposobnosti između grupa testirana je metodom multivarijantne analize varijanse (MANOVA). Rezultati istraživanja ukazuju da gojazne devojčice imaju problema $u$ varijablama koje su procenjivale eksplozivnu snagu donjih ekstremiteta, brzinu trčanja i repetitivnu snagu. Nisu utvrđene značajne razlike za varijable koje procenjuju segmentarnu brzinu, fleksibilnost, preciznost, ravnotežu, eksplozivnost mišića kranijalnog dela tela i koordinaciju.

Ključne reči: gojaznost, motoričke sposobnosti, devojčice 